\title{
Cognitive Science and Theological Education in Technologically Developing Countries
}

\author{
David R. Dunaetz
}

Azusa Pacific University

\begin{abstract}
Cognitive science is the interdisciplinary study of human thoughts, feelings, and the associated processes, including learning. In the past 50 years, tremendous progress has been made in understanding how people learn. These principles can be used to make theological education more effective in the majority world. Missionaries and other educators can make theological education more effective by being familiar with the concepts of automatic and effortful processing, the spacing effect, and the testing effect. Since the use of technology is rapidly evolving in many parts of the world, cognitive science also provides insights into some of the educational pitfalls associated with technology. Technology-based distraction in the classroom prevents effortful processing from occurring. Outside of the classroom, technology may make time-management more difficult, leading to poor study habits. An inappropriate use of multimedia in the classroom may impede learning rather than enhance it. Increasing use of technology in the majority world is often accompanied by economic growth which may also impact theological education. Although incredible diversity exists among humans, there is sufficient similarity in human minds across cultures to scientifically study how a person's thoughts, feelings, and behavior influence each other. Cognitive science is the broad, interdisciplinary field that examines the psychological and biological phenomena associated with the mind. Because the human mind is so complex, progress in the field is often painstakingly slow, especially when compared to the progress that has been made in the physical sciences. Although we can predict with a good deal of accuracy what a molecule or a nearby star will do in a year or in a century from now, we have a very difficult time predicting what our next-door neighbor will do tomorrow. Nevertheless, cognitive science has enabled us to discover general trends that describe how humans are likely to behave in various circumstances, although we will never be able to predict exactly how a specific individual would act in those circumstances.
\end{abstract}

For many Christians, anything having to do with psychology is of questionable value. Some equate psychology with the speculative assumptions of psychoanalysis developed by Sigmund Freud (1856-1939; e.g., Freud, 1923, 1962) which have long been downplayed, if not discredited, by scientists (Dufresne, 2007; Eysenck, 1991; Stanovich, 2013). After World War II, the dominant paradigm in psychology was behaviorism (Skinner, 1971; Watson, 1926) which was more scientific in nature but was still quite unacceptable from a Christian point of view. Behaviorists such as Watson and Skinner believed that human behavior depended uniquely on a person's background and the current environment. From a behaviorist point of view, thoughts, feelings, beliefs, values, and other cognitive phenomena were irrelevant to behavior, mere artifacts of evolution that gave humans the illusion of freewill and for which humans could not be held accountable.

However, by the 1960 s, psychologists began to realize that mental states and processes did indeed influence behavior and could be studied relatively objectively, albeit imprecisely. As these mental states and 
Dunaetz, D. R. (2018). Cognitive science and theological education in technologically developing countries. International Journal of Frontier Missiology, 35(3), 135-143.

processes were studied, it became clear that the experimental evidence pointed to the mind, not as a blank slate, but as a preprogrammed organ that tended to learn, interpret, and create in predictable ways across individuals and across cultures (Pinker, 2002). By the 1980s this approach to studying the human mind became dominant in the field, a change which has become known as the cognitive revolution (Miller, 2003) ${ }^{1}$.

This new focus on the mind has made psychology as a science much more compatible with Christian theology. Rather than assuming that human beings are born as a blank slate, they are assumed to be born with a specific nature common to all humans, yet also with individual differences. The role of science is thus to discover and describe this nature and to describe how it, along with individual differences and the environment, influences human behaviors such as learning, communication, and social interaction. This is perfectly congruent with Christian theology which teaches that human nature most certainly exists and is characterized by, if not defined by, both the image of God (צֶלֶם אֶלהּהים, Gen. 1:26-28) and sinfulness (Rom. 3:23, Eph. 2:3).

Thus insights gained from cognitive science concerning learning (such as in a context of theological education), to the degree that they are true and are based upon an accurate understanding of human behavior, can enable Christian missionaries, educators, and students to become more effective in the areas to which God has called them. Here, we will focus upon learning, which is one of the principal goals of theological education. Learning can be defined as "the process of acquiring new and relatively enduring information or behaviors" (Myers \& DeWall, 2015 ; p. 280). This definition is especially appropriate for theological education because it includes the concept of acquiring both information and behaviors. Theological educators certainly want their students to master information about the Bible, church history, and theology, but theological education is not limited to learning information. It includes acquiring new behaviors which range from administering baptism and performing weddings to exegeting a biblical passage and presenting an effective sermon on it. In addition, theological education may include elements of character development, which manifests itself through new behaviors which are constructive and consistent.

Because it can occur in many different contexts, for the purpose of this study, theological education will be defined as the complex process by which students, in an institutional context, learn new and enduring information and behaviors that are relevant to Christian life and ministry (cf. Myers \& DeWall, 2015, p. 280). These institutions may be schools, churches, or any other organization with theological education as one of its goals. Institutional based learning differs from other types of learning in several ways. First, the material presented to the student is not presented in its normal, day-to-day context as a student might naturally encounter it (e.g., responses to attacks on Christianity by a non-Christian friend) and, second, the material is primarily transmitted through language (oral and/or written), rather than by watching other people model it (e.g., the biblical concept of forgiveness) (Bruner, Olver, \& Greenfield, 1966; Scribner \& Cole, 1973).

Before examining principles from cognitive science that may be useful for theological education in developing countries, the question of whether the underlying cognitive phenomena are culturally universal or are culturally relative should be asked. This is an important question because much of cognitive science has been developed by studying people who are white, educated, industrialized, rich, and democratic (commonly known as WEIRD; Henrich, Heine, \& Norenzayan, 2010a, 2010b), whereas most people in the world are not.

Some cognitive functions are clearly universal. People of all cultures use the five senses to gain information about their physical and social environment. People of all cultures use language to communicate within their ingroup. People of all cultures can also learn cultural information in a classroom setting (Bruner, 1960).

Other cognitive functions differ from culture to culture. This is at least partially due to differences in cultural schemas, cognitive structures and categories representing regularities in patterns regularly encountered in one's culture (Baldwin, 1995; Nishida, 1999). Similarly, language structures influence beliefs about the world. Languages vary in the vocabulary available to describe differences in nuances, both in physical domains (e.g., colors or weather-related phenomena) and the psychological (e.g., emotions or commitment). These vocabulary differences, as well as grammatical structures that exist in a language (e.g., tenses), influence how members of a culture think, feel, and behave (Myers \& DeWall, 2015; Whorf, 1956). Other cognitive phenomena that differ by culture include perceptions of fairness and cooperation, moral reasoning, and self-concept (Henrich, et al., 2010b).

So there are some cognitive processes that vary according to culture and others that are common to all humans. The processes that are purely biological and are fundamental to human nature tend to be culturally universal. The processes that are learned and are influenced by the environment tend to be culturally relative. However, it is often difficult to distinguish between these. As a rule of thumb, one can assume that, apart from evidence to the contrary, human cognitive processes are at least similar between cultures, if not identical. However, if there is evidence that cultural differences in cognitive processes exist, these need to be taken into account because the phenomena may very well be culturally relative.

The phenomena and models described in this study currently appear to be culturally universal. They include automatic and effortful processing, the spacing effect, and the testing effect. However, as our knowledge and understanding of culture increases, it would not be
${ }^{1}$ The cognitive revolution occurred primarily in America. European psychologists had not adopted a behaviorist perspective to the degree than American psychologists had and thus continued to consider mental processes in their study of human behavior. In other contexts (e.g., the biblical world or other non-Western cultures), the importance of thoughts and beliefs, and how they relate to behaviors, had never been doubted. 
Dunaetz, D. R. (2018). Cognitive science and theological education in technologically developing countries. International Journal of Frontier Missiology, 35(3), 135-143.

surprising to find at least some small differences between cultures of how these phenomena play out. To complicate matters, all cultures are evolving (Mesoudi, Whiten, \& Laland, 2006) and this cultural evolution is accelerating, at least in part, due to technology (Rosa, 2003). Because of the rapidity of technology-driven cultural change, a special emphasis will be placed on the influence that technology can have on the cognitive processes and phenomena involved in theological education in the majority world.

\section{Automatic and Effortful Processing}

When theological students (and everyone else) are exposed to new information, some type of processing must occur in their brain before one can say that the material has been learned to some degree or another. Cognitive scientists distinguish between low elaboration and high elaboration strategies to describe ways that the information can be processed and how beliefs and attitudes are formed (Chaiken, 1980; Kahneman, 2011; Petty \& Cacioppo, 1986a, 1986b). The type of elaboration strategy used influences how well a person learns material and the strength of their beliefs that form about the material.

Low elaboration strategies use automatic processing to store the perceptions made by the source of the new information. This is sometimes called System 1 thinking (Kahneman, 2011) and is said to use the peripheral route through the brain. Automatic processing is fast and does not require much, if any, effort, but it does not critically evaluate the content of the material concerning its truth or relevance. Rather, the environment of the message influences its impact. For example, automatic processing occurs in theological education when a student receives and evaluates information positively because he or she believes the professor to be credible and authoritative, because the teacher is attractive or charismatic, or because the professor presents the information in a catchy or humorous way. In automatic processing, the learner uses these and other mental shortcuts (heuristics) rather than evidence and reason to evaluate the material. This type of learning requires far less effort than more in depth processing, but is less stable, less resistant to counter arguments, and less likely to influence the learner's behavior than learning that involves in-depth processing (Chaiken, 1980; Eagly \& Chaiken, 1998).

High elaboration strategies, on the other hand, require effortful processing rather than automatic processing (Petty, 2013; Petty \& Cacioppo, 1986a, 1986b). This is also known as System 2 thinking (Kahneman, 2011) and is said to use the central route through the brain. Effortful processing only occurs when a person is both willing and able to put in the time and effort necessary to comprehensively analyze the material being presented. Rather than focusing on the source or context of the material, this type of processing focuses on the content of the material. Learners are typically willing to put forth the effort necessary for effortful processing when they believe that the material will personally affect their lives depending on whether it is true or not.

For theological education, this means that the primary role of the professor is not only to provide access to new information, but also to ensure that the student effortfully processes the material. Education that consists of listening to lectures, reading texts, and then rereading the texts (and even highlighting key points) generates less effortful processing than education that includes writing (whether summarizing, elaborating, or applying the material), discussion, and testing, especially when these elements are clearly seen to be directly relevant to the student's previous experiences and ministry (Dunlosky, Rawson, Marsh, Nathan, \& Willingham, 2013; Fowler \& Barker, 1974). Assuming that all theological students in a given context will have access to the material that they need to learn through lectures or books, we can safely predict that the amount that each student learns will be proportional to his or her effortful processing of this material. The most effective professors are thus those who maximize effortful processing in their students, creating desirable difficulties that lead to greater learning (Bjork, Dunlosky, \& Kornell, 2013; Kornell \& Bjork, 2007).

\section{The Testing Effect}

One way to increase effortful processing (and thus learning) is through testing, either non-graded self-testing or graded testing that is part of the curriculum. The testing effect describes the phenomena whereby people who have been tested on material they have studied remember it better than those who have not been tested on it, even when the amount of studying is the same (McDaniel, Anderson, Derbish, \& Morrisette, 2007; Roediger \& Karpicke, 2006). This phenomena is especially true when the tests are composed of questions that require a higher level of processing (such as analysis, evaluation, or application) than questions that require a lower level of processing, such as recalling facts (Jensen, McDaniel, Woodard, \& Kummer, 2014; Wooldridge, Bugg, McDaniel, \& Liu, 2014).

There are at least several mechanisms behind the testing effect. First, from a biological perspective, retrieval practice through testing strengthens neural pathways linking concepts that increase recall ability (Liu, Liang, Li, \& Reder, 2014; Wing, Marsh, \& Cabeza, 2013). Although retrieving information and processing it for analysis, evaluation, or application is difficult the first time, it becomes easier with practice and the ability to do so becomes more permanent. Thus while it might be initially difficult for a theological student to respond to the test prompt "What would you say to a member of a youth group who is considering becoming a Muslim?", the second time he or she faces the prompt (or an actual youth group member), the response will require less effort.

Second, from a motivational point of view, the testing effect occurs because testing typically motivates people to use high elaboration strategies and expend the effort necessary to thoroughly process the material. Selfdetermination theory (Deci \& Ryan, 2008; Ryan \& Deci, 2000 ) is useful for understanding how testing may increase motivation. Motivation can be either extrinsic (directed towards seeking external rewards) or intrinsic (directed towards meeting internal, psychological needs). Testing in theological education can produce extrinsic motivation if the student believes that mastering the material (or at least doing well on the test) will lead to higher grades, a better 
Dunaetz, D. R. (2018). Cognitive science and theological education in technologically developing countries.

internship, a higher salary, or any other perceived reward coming from an outside source. However, such motivation persists only as long as the prospect of gaining such a reward is a possibility.

Intrinsic motivation, on the other hand, is more permanent and not conditioned by external forces. Selfdetermination theory (Deci \& Ryan, 2008; Ryan \& Deci, 2000) argues that intrinsic motivation for a behavior (such as studying material for a test) increases to the degree that the behavior increases one's sense of competence, autonomy, and relatedness. Theological students, like all humans, want to be competent, to gain mastery over their environment in order to achieve their life goals. If they believe that studying the material in a class may increase their competency, they will be likely to study for a test. The role of the theological educator in this case is to demonstrate that the material is related to competencies necessary to achieve their life goals. For example, if a theological student desires to serve the Lord full-time in a local church, the educator can increase motivation to study for a test on the Pentateuch by demonstrating how mastery of the Pentateuch can make that person a more effective minister, such as by providing a foundation of creation theology or interpersonal ethics. Students who do well on a test measuring these competencies will increase their internal motivation to use these competencies in real life situations. In contrast, those who do not do well will be less motivated to try to use these competencies.

Self-determination theory (Deci \& Ryan, 2008;

Ryan \& Deci, 2000) also predicts that intrinsic motivation to perform a behavior will increase with autonomy, the feeling that one can freely choose to perform the behavior or not. For the theological educator, this implies that instruction should not simply teach the "correct" way to do things (baptize, perform a marriage, preach a sermon, start a church, etc.), but should provide instruction and examples concerning a number of means and strategies for accomplishing these tasks. This enables theological students to choose the approach which best corresponds to their personality, gifting, and context. Being able to choose among different approaches will increase their sense of both competence and autonomy, increasing their motivation to perform the task. Testing students with questions that ask them to compare and evaluate methods and strategies to accomplish ministry tasks are especially useful for developing this sense of autonomy.

The promise of high quality relationships also increases intrinsic motivation according to selfdetermination theory (Deci \& Ryan, 2008; Ryan \& Deci, 2000). Being created in the image of God whose fundamental nature is love (1 John 4:7-8) implies that humans are innately social. Furthermore, we do not simply desire relationships with others, but high quality relationships which are mutually beneficial cognitively, emotionally, and spiritually. If a Bible professor teaching a course in the prison epistles can demonstrate how mastery of the material will increase the quality of students' relationships, the students will be more motivated to study the material. Tests that focus on applications of the biblical content are especially relevant to help the student focus on improved relationships. Prompts such as "How did Paul express his thankfulness to the Philippians?" or "Cite several Pauline principles of conflict resolution." encourage students to think in terms of relationships and motivate them to master the concepts in order to improve their relationships.

\section{The Spacing Effect}

One of the most important ways that cognitive scientists have discovered to increase retention of abstract material is distributed practice in contrast to massed practice (Cepeda, Pashler, Vul, Wixted, \& Rohrer, 2006; Ruch, 1928).

Distributed practice is studying material over a period of time, coming back to it after breaks (ranging from minutes to weeks) whereas massed practice is doing all of the studying at once, commonly known as cramming. The difference in learning that occurs under these two conditions is known as the spacing effect (Kapler, Weston, $\&$ Wiseheart, 2015). The studying effort spaced over a longer period of time leads to more permanent learning than does the same amount of studying massed together. For example, studying a language a little bit each day, or even several times a week, will lead to better retention than studying for the same total amount of time once a week in one sitting (Bahrick, Bahrick, Bahrick, \& Bahrick, 1993).

In addition to encouraging students to study regularly, this means that effective professors will design their courses so that students are repeatedly exposed to the material in a cognitively challenging way multiple times during the quarter or semester. Quick learning essentially leads to quick forgetting (Cepeda, et al., 2006; Ebbinghaus, $1885 / 1913)$. The physical phenomena behind the spacing effect is that repeated processing of given material creates longer lasting neural pathways. Like the testing effect, repeated exposure to material makes it easier to recall, especially when needed (Sisti, Glass, \& Shors, 2007). Several psychological and behavioral phenomena lie behind the spacing effect as well.

First, processing of the material being studied continues to be processed by the unconscious brain in between study sessions in a process known as incubation (Sio \& Ormerod, 2009; Smith \& Blankenship, 1991). This process is at least partially responsible for the eureka effect whereby a person has a flash of insight concerning a problem about which he or she is not consciously thinking (Jung-Beeman et al., 2004; Perkins, 2001). A theological student who does not understand a difficult concept (e.g., the relationship between faith and works) may not get the information the first or second time he or she studies the relevant biblical texts. However, during a flash of insight sometime later, the relationship may become clearer. A third session of studying the relevant biblical texts would allow the incorporation of the new insight into the student's understanding of the faith and works, cementing the students convictions by strengthening his or her beliefs (Dunaetz, 2016).

A second learning-enhancing phenomena that occurs during the spacing effect is the incorporation of new and relevant experiences into one's developing schemas (Shors, 2014; Sisti, et al., 2007). If students are studying about baptism in a theology class, they might receive some basic arguments for or against different modes. The material might not generate much cognitive reflection 
Dunaetz, D. R. (2018). Cognitive science and theological education in technologically developing countries. International Journal of Frontier Missiology, 35(3), 135-143.

because there are so many other equally interesting concepts presented in the class, especially if the professor's preferred baptismal mode corresponds to that of the students' background. However, if a student encounters someone in the coming weeks who prefers a different mode of baptism, the student's interest is piqued and additional reflection occurs. Without distributed practice, what the student learned originally might not evolve. However, if the professor assigns additional assignments or tests that concern arguing for or against a mode of baptism, deep level processing is more likely to occur in students who can add recent experiences into their thought process as they develop their argument. Students who cover the question of baptism all at once in the semester will not have this advantage. Students who are exposed to the topic several times during the semester will have the advantage of being forced to integrate their new experiences into their learning. A third phenomena that occurs with spaced study periods in contrast to a massed study period is simply the testing effect (Putnam, Sungkhasettee, \& Roediger, 2016; Roediger \& Karpicke, 2006). When students encounter new material on a topic, they are, to a certain degree, tested on the previously covered material. Cognitive effort is required to recall the material on the topic, perhaps with significant priming from the professor, which strengthens the neural pathways associated with the concept and makes the material easier to recall when needed.

Because interacting with material several times over a long period is a more effective way to learn than is concentrated exposure to the same amount of material (Kapler, et al., 2015; Putnam, et al., 2016), theological educators can organize their classes and motivate their students appropriately:

- Professors should encourage regular studying and reviewing after each class period rather than cramming before exams. It is useful to inform students that this is a more effective way to study because students tend to believe that massing is more effective than distributed practice (Son \& Simon, 2012).

- Learning will be more permanent in classes that meet several times per week rather than just once a week or once a month. Frequent exposure to the material is more effective than longer, infrequent exposure to the material.

- Longer semesters are more effective than shorter semesters. Shorter semesters provide less opportunity to process and apply the material and there are fewer opportunities to integrate new, relevant experiences into the course.

- Short, frequent assignments are more effective than fewer, long assignments. Students should be asked to review, analyze, and apply the material shortly after its initial presentation to strengthen their understanding of the concepts so that they may continue to build upon them.

- $\quad$ Frequent, cumulative quizzes and tests are more effective than fewer, non-cumulative quizzes and tests and much more effective than no testing or quizzing. Increasing the number of quizzes and tests increases learning through both the testing effect and the spacing effect.
Although the spacing effect is one of the most strongly supported phenomena in the cognitive sciences, implementing strategies that increase learning through this phenomena are often met with resistance by students, professors, or administrators. Such strategies often require more time, effort, and resources than strategies that encourage massing. Nevertheless, as faithful stewards of that which God has entrusted us, we need to consider what is in the best interest of theological students and the people whom God is calling them to serve.

\section{Technology-Related Pitfalls}

Much of the majority world is characterized by rapid adoption of electronic technology. Because the technology gap was so large during the Cold War era between developed and developing nations, the adoption of technology has been around 50\% faster in the majority world than in the West since then, but a gap still exists (The World Bank, 2008). This has enormous implications for theological education in the majority world, providing both opportunities and pitfalls.

Although contemporary electronic technology in majority world contexts permits the use of media of in the classroom (e.g., PowerPoints and YouTube), facilitates communication (e.g., email and texting), makes scholarship accessible (e.g., Google Scholar and ResearchGate), and permits paperless classroom management at a distance (e.g., Moodle and Canvas), technology can also reduce learning in theological education. Research in the cognitive sciences provides insights into how to avoid some of the dangers associated with technology.

Perhaps the most obvious danger associated with technology is distraction in a classroom. Although humans believe they can multitask, they really only can give their attention to one event or activity at a time (Driver, 1998; Kaplan \& Berman, 2010; Pashler \& Johnston, 1998). Attention is a process by which a person perceives information from one source while ignoring information from other sources (Pashler, 1998). This choice concerning one's focus may be either conscious or unconscious. If too much information is available, bottlenecking occurs which causes some information to not be perceived. This permits the information that is the focus of one's attention to be processed and acted upon, although other information is ignored and has little influence on a person (Simon, 1994).

This means that students tend to believe that they can surf the internet on their cell phones or laptops during a lecture deemed boring, yet keep an ear open in case the professor says anything important or interesting. In reality, these students miss much information that would increase their learning. Forbidding both cell phone use (Beland \& Murphy, 2016) and internet access in classroom (Wood et al., 2012) increases learning as demonstrated by higher test scores. In addition, other students who can see another student's screen are often distracted due to no fault of their own (Fried, 2008). Messaging apps and social networks are often the greatest distraction in developed countries (Junco \& Mastrodicasa, 2007) and there is little reason to doubt that a similar phenomenon occurs in the majority world where people tend to be more collectivistic than 
Dunaetz, D. R. (2018). Cognitive science and theological education in technologically developing countries. International Journal of Frontier Missiology, 35(3), 135-143.

individualistic.

The question thus arises, "Should theological educators ban the use of computers and cell phones in the classroom?" Mueller and Oppenheimer (2014) found through a series of experiments that students who took lecture notes by hand learned more than students who took notes on their computer as demonstrated by their response to conceptual questions on a test. Even when not distracted by the internet, computer users tended to focus their attention on copying material verbatim whereas students taking handwritten notes processed the information to put it into their own words. This means that theological educators can increase learning by forbidding the use of computers and cell phones in the classroom because this both reduces distractions and encourages deeper level processing. Certainly in some classes, the use of a computer would be beneficial (e.g., a course in media use for evangelism), but in many classes it is in the students' interest to forbid its use.

Another threat to theological education associated with technology concern the students' time management outside of the classroom. The internet provides a virtually unlimited source of amusing cat videos and other sources of entertainment (Myrick, 2015). Internet-based entertainment is often effective as a mood enhancer, but it is also motivates procrastination and the negative effects that accompany it (Myrick, 2015; Steel, 2007). This makes time management more difficult for students. They may have every intention of studying, but the draw of internet entertainment and social media may severely restrict the time that they can consecrate to their studies. Because this phenomena is relatively new, a given culture may have few effective strategies for overcoming this difficulty. Theological educators should thus consider introducing time management strategies into the curriculum. In many cultures, calendars and to-do lists would be very appropriate, both of which can be managed through technology (e.g., Google Calendar, Microsoft Note), often more effectively than through traditional handwritten approaches. A wide variety of time management apps exist (e.g., Timeful, Focus Booster, and Remember the Milk) which increases the likelihood of finding a culturally appropriate tool. So by beginning the semester with the presentation of several time management strategies, a theological educator would likely enable his or her students to study more and thus learn more during the semester.

The inappropriate use of media by the professor in the classroom is another threat to effective theological education. As mentioned earlier, students who take notes on a computer process the information less than those who take notes by hand (Mueller \& Oppenheimer, 2014). This is especially true for PowerPoint presentations which are often presented at a rate that is comfortable for the professor but not the students (Putnam, et al., 2016). Elizabeth Marsh and Holly Sink of Duke University (2010) have demonstrated that students typically learn better from a PowerPoint presentation if they are given paper copies of the slides before the lecture than if they took all their notes themselves. Such handouts increased student satisfaction, reduced time needed to study, and increased test scores. Print-on-demand publishers (e.g., Createspace.com) permit professors to publish lecture notes or other handouts in the form of a soft-cover book at a price of $1 \%-3 \%$ of a typical U.S. textbook and at about half the price of photocopies, without a need to print a minimum number of copies (e.g., Dunaetz, 2017). Such books are an economical way to enhance the effectiveness of PowerPoint based lectures.

The increased use of technology in the majority world is strongly associated with economic growth (Chatterji, 2016; The World Bank, 2008). Economic growth is generally a desirable phenomenon, but some side effects may effect theological education in the developing world. Theological institutions started by missionaries are initially dependent on outside funds. Those who control the funds have a large say in defining the mission of the institution (e.g., training workers for full-time Christian service). However, as the national church and local economy grow, the likelihood of the institution supporting itself grows as well. This has long been a goal of many mission organizations (e..g., Venn, 1865). However, once an institution needs to support itself, including its salaried staff, it is easy for its mission to drift. The leaders of the organization, especially Christian leaders, are likely to feel responsible for the well-being of the employees of the organization, a phenomena often associated with servant leadership (Mark 9:35; Greenleaf, 1977). Because of loss aversion (Kahneman \& Tversky, 1979; Kermer, DriverLinn, Wilson, \& Gilbert, 2006), the immediate threat of hurting coworkers seems more serious than a change of mission for the school. Our brain essentially tells us (through subjective feelings) that the loss associated with hurting someone (e.g., laying off a colleague due to lack of funds) is greater than the long term benefits of focusing on the established mission of the theological institution. So leaders may conclude that if they make the mission of the organization broader (e.g., providing a theological education to everyone who is interested vs. preparing ministers who have been recognized by their churches for full-time ministry), they can meet the needs of both the students and the employees, while maintaining their own salaries as well.

When the focus of the institution changes to concern for economic stability, student satisfaction or engagement may become more important than student learning. By focusing on satisfaction or engagement, student retention will increase (Kuh, Kinzie, Schuh, \& Whitt, 2011) which helps meet the financial needs of the organization. However, with an increased emphasis on meeting student desires, it is quite possible that academic standards and learning decrease (Trow, 1987). Since maximizing learning requires effortful processing, higher standards are resisted by students; weaker students are especially discouraged by higher standards and are more likely to drop out, taking their tuition with them. There are no easy solutions to the tensions created by a need for stability and the desire to maintain and fulfill the original mission of a school. However, being aware of the cognitive processes involved can help leaders of theological institutions make wiser decisions.

\section{Conclusion}

If one of the main goals of theological education is to 
Dunaetz, D. R. (2018). Cognitive science and theological education in technologically developing countries. International Journal of Frontier Missiology, 35(3), 135-143.

prepare students for ministry, students need to learn the knowledge and skills that will make them effective ministers of Jesus Christ. Schools can encourage this learning in ways that are effective or ineffective, or anywhere in between. By being aware of some of the cognitive phenomena that can enhance learning, such as effortful processing, the testing effect, and the spacing effect, administrators and professors at theological institutions, especially those in technologically developing countries, can encourage effective practices that will prepare students to use all their gifts for the service of the gospel.

\section{References}

Bahrick, H. P., Bahrick, L. E., Bahrick, A. S., \& Bahrick, P. E. (1993). Maintenance of foreign language vocabulary and the spacing effect. Psychological Science, 316-321.

Baldwin, M. W. (1995). Relational schemas and cognition in close relationships. Journal of Social and Personal relationships, 12, 547-552.

Beland, L. P., \& Murphy, R. (2016). Communication: Technology, distraction \& student performance. Labour Economics, 41, 61-76.

Bjork, R. A., Dunlosky, J., \& Kornell, N. (2013). Selfregulated learning: Beliefs, techniques, and illusions. Annual Review of Psychology, 64, 417444.

Bruner, J. S. (1960). The process of education. Boston, MA: Harvard University Press.

Bruner, J. S., Olver, R. R., \& Greenfield, P. M. (1966). Studies in cognitive growth. Oxford, UK: Wiley.

Cepeda, N. J., Pashler, H., Vul, E., Wixted, J. T., \& Rohrer, D. (2006). Distributed practice in verbal recall tasks: A review and quantitative synthesis. Psychological Bulletin, 132, 354-380.

Chaiken, S. (1980). Heuristic versus systematic information processing and the use of source versus message cues in persuasion. Journal of Personality and Social Psychology, 39, 752-766.

Chatterji, M. (2016). Technology transfer in the developing countries. New York, NY: Springer.

Deci, E. L., \& Ryan, R. M. (2008). Self-determination theory: A macrotheory of human motivation, development, and health. Canadian Psychology/Psychologie Canadienne, 49, 182185.

Driver, J. (1998). The neuropsychology of spatial attention. In H. Pashler (Ed.), Attention (pp. 297-340). Hove, UK: Psychology Press.

Dufresne, T. (2007). Against Freud: Critics talk back. Stanford, CA: Stanford University Press.

Dunaetz, D. R. (2016). Missio-logoi and faith: Factors that influence attitude certainty. Missiology: An International Review, 44, 66-77.

Dunaetz, D. R. (2017). Research methods and survey applications: Outlines and activities from a Christian perspective. Claremont, CA: Martel Press.

Dunlosky, J., Rawson, K. A., Marsh, E. J., Nathan, M. J., \& Willingham, D. T. (2013). Improving students' learning with effective learning techniques: Promising directions from cognitive and educational psychology. Psychological Science in the Public Interest, 14, 4-58.

Eagly, A. H., \& Chaiken, S. (1998). Attitude structure and function. In D. T. Gilbert, S. T. Fiske \& G. Lindzey (Eds.), The handbook of social psychology (4th ed., pp. 269-322). Boston, MA: McGraw Hill.

Ebbinghaus, H. (1885/1913). Memory: A contribution to experimental psychology. New York, NY: Columbia University.

Eysenck, H. J. (1991). Decline and fall of the freudian empire. New Brunswick, NJ: Transaction Publishers.

Fowler, R. L., \& Barker, A. S. (1974). Effectiveness of highlighting for retention of text material. Journal of Applied Psychology, 59, 358-364.

Freud, S. (1923). The ego and the id. London: Hogarth Press.

Freud, S. (1962). The aetiology of hysteria. In A. Freud \& J. Strachy (Eds.), The standard edition of the complete psychological works of sigmund Freud (Vol. III, pp. 187-221). London, UK: Hogarth Press.

Fried, C. B. (2008). In-class laptop use and its effects on student learning. Computers \& Education, 50, 906-914.

Greenleaf, R. K. (1977). Servant leadership: A journey into the nature of legitimate power and greatness. New York, NY: Paulist Press.

Henrich, J., Heine, S. J., \& Norenzayan, A. (2010a). Most people are not WEIRD. Nature, 466, 29.

Henrich, J., Heine, S. J., \& Norenzayan, A. (2010b). The weirdest people in the world. Behavioral and Brain Sciences, 33, 61-135.

Jensen, J. L., McDaniel, M. A., Woodard, S. M., \& Kummer, T. A. (2014). Teaching to the test... or testing to teach: Exams requiring higher order thinking skills encourage greater conceptual understanding. Educational Psychology Review, 26, 307-329.

Junco, R., \& Mastrodicasa, J. (2007). Connecting to the net generation: What higher education professionals need to know about today's students. Washington, DC: NASPA.

Jung-Beeman, M., Bowden, E. M., Haberman, J., Frymiare, J. L., Arambel-Liu, S., Greenblatt, R., ... . Kounios, J. (2004). Neural activity when people solve verbal problems with insight. PLoS Biology, 2, e97.

Kahneman, D. (2011). Thinking, fast and slow. New York, NY: Farrar, Straus and Giroux.

Kahneman, D., \& Tversky, A. (1979). Prospect theory: An analysis of decision under risk. Econometrica: Journal of the Econometric Society, 263-291.

Kaplan, S., \& Berman, M. G. (2010). Directed attention as a common resource for executive functioning and self-regulation. Perspectives on Psychological Science, 5, 43-57.

Kapler, I. V., Weston, T., \& Wiseheart, M. (2015). Spacing in a simulated undergraduate classroom: Long- 
Dunaetz, D. R. (2018). Cognitive science and theological education in technologically developing countries.

term benefits for factual and higher-level learning. Learning and Instruction, 36, 38-45.

Kermer, D. A., Driver-Linn, E., Wilson, T. D., \& Gilbert, D. T. (2006). Loss aversion is an affective forecasting error. Psychological Science, 17, 649653.

Kornell, N., \& Bjork, R. A. (2007). The promise and perils of self-regulated study. Psychonomic Bulletin \& Review, 14, 219-224.

Kuh, G. D., Kinzie, J., Schuh, J. H., \& Whitt, E. J. (2011). Student success in college: Creating conditions that matter. San Francisco, CA: Jossey-Bass.

Liu, X. L., Liang, P., Li, K., \& Reder, L. M. (2014). Uncovering the neural mechanisms underlying learning from tests. PloS one, 9, e92025.

Marsh, E. J., \& Sink, H. E. (2010). Access to handouts of presentation slides during lecture: Consequences for learning. Applied Cognitive Psychology, 24, 691-706.

McDaniel, M. A., Anderson, J. L., Derbish, M. H., \& Morrisette, N. (2007). Testing the testing effect in the classroom. European Journal of Cognitive Psychology, 19, 494-513.

Mesoudi, A., Whiten, A., \& Laland, K. N. (2006). Towards a unified science of cultural evolution. Behavioral and Brain Sciences, 29, 329-347.

Miller, G. A. (2003). The cognitive revolution: A historical perspective. Trends in cognitive sciences, 7, 141144.

Mueller, P. A., \& Oppenheimer, D. M. (2014). The pen is mightier than the keyboard: Advantages of longhand over laptop note taking. Psychological Science, 25, 1159-1168.

Myers, D. G., \& DeWall, C. N. (2015). Psychology (11th ed.). New York, NY: Worth Publishers.

Myrick, J. G. (2015). Emotion regulation, procrastination, and watching cat videos online: Who watches internet cats, why, and to what effect? Computers in Human Behavior, 52, 168-176.

Nishida, H. (1999). Cultural schema theory. In W. B. Gudykunst (Ed.), Theorizing about intercultural communication (pp. 401-418). Thousand Oaks, CA: Sage.

Pashler, H. (1998). Attention. Hove, UK: Psychology Press.

Pashler, H., \& Johnston, J. C. (1998). Attentional limitations in dual-task performance. In $\mathrm{H}$. Pashler (Ed.), Attention (pp. 155-190). Hove, U.K.: Psychology Press.

Perkins, D. N. (2001). The eureka effect: The art and logic of breakthrough thinking. New York, NY: WW Norton \& Company.

Petty, R. E. (2013). Two routes to persuasion: State of the art. International Perspectives on Psychological Science, 2, 229-247.

Petty, R. E., \& Cacioppo, J. T. (1986a). Communication and persuasion: Central and peripheral routes to attitude change. New York, NY: Springer.

Petty, R. E., \& Cacioppo, J. T. (1986b). The elaboration likelihood model of persuasion. Advances in experimental social psychology, 19, 123-205.

Pinker, S. (2002). The blank slate: The modern denial of human nature. New York, NY: Penguin Books.
Putnam, A. L., Sungkhasettee, V. W., \& Roediger, H. L. (2016). Optimizing learning in college tips from cognitive psychology. Perspectives on Psychological Science, 11, 652-660.

Roediger, H. L., \& Karpicke, J. D. (2006). Test-enhanced learning: Taking memory tests improves longterm retention. Psychological science, 17, 249255.

Rosa, H. (2003). Social acceleration: Ethical and political consequences of a desynchronized high-speed society. Constellations, 10, 3-33.

Ruch, T. C. (1928). Factors influencing the relative economy of massed and distributed practice in learning. Psychological Review, 35, 19-45.

Ryan, R. M., \& Deci, E. L. (2000). Self-determination theory and the facilitation of intrinsic motivation, social development, and well-being. American Psychologist, 55, 68-78.

Scribner, S., \& Cole, M. (1973). Cognitive consequences of formal and informal education. Science, 182, 553-559.

Shors, T. J. (2014). The adult brain makes new neurons, and effortful learning keeps them alive. Current Directions in Psychological Science, 23, 311318.

Simon, H. A. (1994). The bottleneck of attention: Connecting thought with motivation. In W. D. Spaulding (Ed.), Integrative views of motivation, cognition, and emotion (pp. 1-21). Lincoln, NE: University of Nebraska Press.

Sio, U. N., \& Ormerod, T. C. (2009). Does incubation enhance problem solving? A meta-analytic review. Psychological Bulletin, 135, 94-120.

Sisti, H. M., Glass, A. L., \& Shors, T. J. (2007). Neurogenesis and the spacing effect: Learning over time enhances memory and the survival of new neurons. Learning \& Memory, 14, 368-375.

Skinner, B. F. (1971). Beyond freedom and dignity. New York, NY: Knopf.

Smith, S. M., \& Blankenship, S. E. (1991). Incubation and the persistence of fixation in problem solving. The American journal of psychology, 61-87.

Son, L. K., \& Simon, D. A. (2012). Distributed learning: Data, metacognition, and educational implications. Educational Psychology Review, 24, 379-399.

Stanovich, K. E. (2013). How to think straight about psychology. Boston, MA: Pearson.

Steel, P. (2007). The nature of procrastination: A metaanalytic and theoretical review of quintessential self-regulatory failure. Psychological Bulletin, 133, 65-94.

The World Bank. (2008). Global economic prospects 2008: Technology diffusion in the developing world. Washington, DC: The World Bank.

Trow, M. (1987). Academic standards and mass higher education. Higher Education Quarterly, 41, 268292.

Venn, H. (1865). Retrospect and prospect of the operations of the Church Missionary Society. London, UK: Church Missionary Society. 
Dunaetz, D. R. (2018). Cognitive science and theological education in technologically developing countries.

International Journal of Frontier Missiology, 35(3), 135-143.

Watson, J. B. (1926). Behaviorism. Journal of Philosophy, 23, 331-334.

Whorf, B. L. (1956). Science and linguistics. In J. B. Carroll (Ed.), Language, thought, and reality: Selected writings of benjamin lee whorf. Cambridge, MA: MIT Press.

Wing, E. A., Marsh, E. J., \& Cabeza, R. (2013). Neural correlates of retrieval-based memory enhancement: An fmri study of the testing effect. Neuropsychologia, 51, 2360-2370.

Wood, E., Zivcakova, L., Gentile, P., Archer, K., De Pasquale, D., \& Nosko, A. (2012). Examining the impact of off-task multi-tasking with technology on real-time classroom learning. Computers \& Education, 58, 365-374.

Wooldridge, C. L., Bugg, J. M., McDaniel, M. A., \& Liu, Y. (2014). The testing effect with authentic educational materials: A cautionary note. Journal of Applied Research in Memory and Cognition, 3, 214-221. 